\title{
Urine Potassium Measurement
}

National Cancer Institute

\section{Source}

National Cancer Institute. Urine Potassium Measurement. NCI Thesaurus. Code C61047.

A quantitative measurement of the total amount of potassium present in a sample of urine. 